\title{
MENJAWAB KESALAHAN KONSEP KRISTOLOGI SAKSI-SAKSI YEHUWA
}

\author{
Berkat Setiaman Harefa \\ Sekolah Tinggi Agama Kristen Terpadu Pesat, Salatiga \\ Email : berkatsetiamanh@gmail.com
}

\begin{abstract}
ion
This writing is intended to answer the lingering error of the Christological Concept of mistaken Jehovah's Witnesses, namely Christ is not a true God, but rather a creation "the

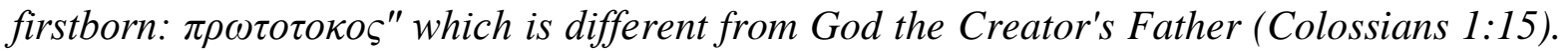
With the method of literature study, this paper chooses the collection of relevant data on Christology to discover the true truth of the reconstruction of the correct Concept of Christology. Therefore, the error is correctly answered that Colossians 1:15 should not be interpreted literally but is interpreted theologically so that the meaning of "the firstborn:

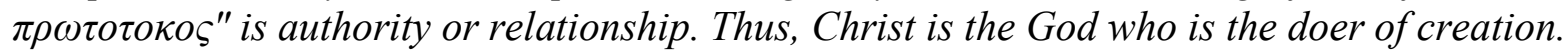

Keywords : Christology, Jehovah's Witnesses, Colossians 1:15.

\begin{abstract}
Abstraksi
Penulisan ini bertujuan menjawab kekeliruan berkepanjangan tentang Konsep Kristologi Saksi-saksi Yehuwa yang keliru, yaitu Kristus bukan Allah sejati, melainkan suatu

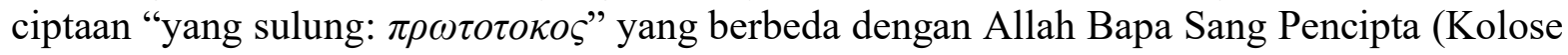
1:15). Dengan metode kajian pustaka, penulisan ini memilih pengumpulan data tentang Kristologi yang relevan untuk menemukan kebenaran sejati terhadap rekonstruksi Konsep Kristologi yang benar. Oleh karena itu, kekeliruan terjawab dengan benar bahwa Kolose 1:15 tidak seharusnya ditafsirkan dengan harfiah, tetapi dimaknai secara teologis sehingga makna

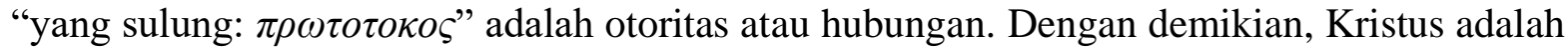
Allah yang merupakan pelaku dari penciptaan.
\end{abstract}

Kata kunci : Kristologi, Saksi-saksi Yehuwa, Kolose 1:15.

\section{PENDAHULUAN}

Dunia Kekristenan, doktrin mengenai Kristus atau yang umum dikenal dengan Kristologi merupakan salah satu doktrin yang hingga kini masih diperdebatkan oleh banyak golongan baik golongan Kekristenan maupun NonKekristenan. Dibalik perdebatan adanya perbedaan persepsi berkepanjangan tentang Kristologi dari golongan Kekristenan itu sendiri sehingga menimbulkan kekeliruan dogma Kristologi dalam Kekristenan. Berdasarkan Alkitab LAI, Kristologi Kristen Protestan dan Kristen Katolik menyadari bahwa Kristus adalah Tuhan (Yohanes 13:13; bnd. Ul. 
6:4; 1 Kor. 8:4). ${ }^{1}$ Sehingga Ia disebut Sang Pencipta. Tetapi pandangan keliru dari golongan Kristen Saksi-saksi Yehuwa menolak doktrin tersebut bahwa Kristus bukan Tuhan.

Penolakan Kristus adalah Tuhan menyadarkan bahwa dogma Kristologi Saksi-saksi Yehuwa menyatakan bahwa Kristus bukanlah Allah melainkan ciptaan. ${ }^{2}$ Ia adalah ciptaan pertama dari Allah, sehingga Ia disebut sebagai "Putra sulung Allah". Yesus adalah satu-satunya putra yang Allah ciptakan sendiri (Lihat Kolose 1:15). Sulung dari segala yang diciptakan tidak berarti Kristus adalah makhluk yang diciptakan. Sebaliknya, "sulung" mengandung makna PL yang sering diberikan kepada: "pertama dalam kedudukan," "ahli waris" atau "tertinggi." (Mis. Kel. 4:22; Yer. 31: 9; Maz. 89:28, di mana kata "yang sulung" dipakai tentang kedudukan Daud sebagai raja, meskipun ia bukan anak yang sulung). ${ }^{3}$ Jadi, sebagai "Putra sulung Allah" yang abadi Kristus adalah ahli waris dan penguasaan atas segala ciptaan (Bnd. Ayat Kol. 1:18; Ibr. 1:1$2){ }^{4}$

Kekeliruan bertambah lagi bahwa Kristus adalah "suatu allah". Ia disebut

\footnotetext{
${ }^{1}$ Everett F. Harrison Charles F. Pfeiffer, The WYCLIFFE Bible Commentary (Volume 3), ed. Emma Maspaitella, V. (Malang: Gandum Mas, 2014).

2 "Apakah Yesus Allah Yang Mahakuasa? | Pertanyaan Alkitab," Diakses Mei 24, 2021.

${ }^{3}$ Charles F. Pfeiffer, The WYCLIFFE
}

"suatu allah" karena Ia merupakan satusatunya "Putra sulung Allah" yang diciptakan sehingga Ia tidak satu dengan Allah Bapa alias bukan Allah sejati. ${ }^{5}$ Para penganut Kristen Saksi-saksi Yehuwa menyembah hanya Allah Bapa saja yang benar dan sejati, dan mengecualikan Allah Anak karena Ia "suatu allah" ciptakan yang tidak lebih dari Allah Bapa. Dengan mainstream dalam penyembahan Kristen Saksi-saksi Yehuwa, tidak menyembah Yesus, dan tidak mengimani sebagai Tuhan dan Juru Selamat sebagai mana dalam Injil Yohanes (Lihat Yohanes 14:6). ${ }^{6}$

Menyadari bahwa Kristologi Saksisaksi Yehuwa merupakan ajaran sesat, karena tidak mungkin Allah menyatakan diri-Nya Esa, jikalau Dia tidak hendak direnungkan sebagai tiga Pribadi yang berbeda-beda. Oleh karena itu, Kristologi Saksi-saksi Yehuwa menyangkali doktrin Tritunggal, bahwa Kristus adalah bukan bagian dari Tritunggal. Sehingga jikalau memang pandangan keliru seperti itu, apakah dasar Alkitab yang mendukung pernyataan mereka? Saksi-saksi Yehuwa mempunyai pandangan Yesus sebagai ciptaan Allah yang pertama (Kolose 1:15) dan kristus adalah putra Allah dan lebih

Bible Commentary (Volume 3).
${ }^{4}$ Ibid.
${ }^{5}$ Roni Ismail, "Konsep Ketuhanan

Menurut Kristen Saksi Yehuwa," Jurnal Sosiologi Agama 10, no. 2 (2017): 83.

${ }^{6}$ Charles F. Pfeiffer, The WYCLIFFE

Bible Commentary (Volume 3). 
rendah daripada Allah (Mat. 3:17; Yoh. $8: 42 ; 14: 28 ; 20: 17 ; 1$ Kor. $11: 3 ; 15: 28){ }^{7}$

Dengan menggunakan ayat-ayat tersebut sebagai fondasi pandangan, Saksisaksi Yehuwa mencoba untuk menyerang dogma Tritunggal yang mengimani ketuhanan Allah, Yesus Kristus dan Roh Kudus sekaligus mengucilkan kredo Pengakuan Iman Rasuli, yaitu Tritunggal yang terdiri dari Allah Bapa, Allah Putra atau Anak, dan Roh Kudus. Bukan hanya itu saja Saksi-saksi Yehuwa meyakinkan orang Kristen dengan pandangan Kristus adalah bukan pencipta. Hal ini menunjukan bahwa masalah ini merupakan masalah yang serius dan harus mendapat penjelasan mendalam.

Berdasarkan kekeliruan Saksi-saksi Yehuwa, maka saya sebagai penulis tergerak hati yang tulus untuk mempertahankan Kristologi yang benar berdasarkan Alkitab. Penulis akan tetap mempertahankan dogma Tritunggal dan kredo Pengakuan Imal Rasuli sebagai tanggungjawab dan penghormatan penulis terhadap bapak-bapak Gereja yang telah membuat ajaran ini dengan bantuan otoritas Allah. Dengan demikian penulis akan menjawab kesalahan konsep

\footnotetext{
${ }^{7}$ Dicky Dominggus, "Kedudukan Kristus Dalam Penciptaan Menurut Kolose 1:15-20 (Tanggapan Kristologi Saksi Yehuwa)," Religi: Jurnal Studi Agama-agama 16, no. 1 (2020): 4263.

${ }^{8}$ John Calvinnis, INSTITUTIO :
}

Kristologi Saksi-saksi Yehuwa berdasarkan kekeliruan eksegesis mereka dari salah satu ayat Alkitab Kolose 1:15.

Dengan penuh hati yang luhur, saya akan memulai tulisan ini dengan perkataan yang ditulis oleh John Calvin sendiri pada karya bukunya "Institutio": Laus Deo: Terpujilah Allah. ${ }^{8}$

\section{METODE PENULISAN}

Dalam penulisan saya ini, sumber data dan informasi yang diperoleh dari berbagai literatur-literatur yang relevan seperti buku, jurnal atau artikel ilmiah yang terkait dengan topik yang dipilih. Kajian kepustakaan (library research) adalah suatu kegiatan pengumpulan data dan informasi-informasi (informations) dari berbagai sumber yang memuat berbagai ragam kajian teori yang sangat dibutuhkan oleh peneliti atau penulis. ${ }^{9}$ Studi kepustakaan (library research) juga berarti mengumpulkan atau menghimpun data dengan mengadakan studi penyelidikan, pemeriksaan terhadap buku-buku, literaturliteratur, artikel-artikel, catatan-catatan dan laporan-laporan yang ada hubungannya dengan masalah yang dipecahkan (Nazir, 2003). ${ }^{10}$

\footnotetext{
Pengajaran Agama Kristen, ed. Staf Redaksi BPK Gunung Mulia, XI. (Jakarta: Gunung Mulia, 2015), http://www.bpkgunungmulia.com.

${ }^{9}$ Juju Suryawati Kin Maryati, Sosiologi (Jakarta: Erlangga, 2007).

${ }^{10}$ Wilda Awalina, "Studi Kepustakaan
} 
Jadi, teknik pengumpulan data yang digunakan dalam penulisan ini, yaitu mencari data mengenai Kristologi atau variabel yang berupa buku, makalah atau artikel, dan jurnal.

\section{PEMBAHASAN}

Kekeliruan Dasar Kristen Saksi-saksi

\section{Yehuwa}

Sebelum meneliti bagaiman pandangan Kristen Saksi-saksi Yehuwa mengenai Kristus, ada baiknya meneliti kekeliruan dasar Kristen Saksi-saksi Yehuwa terlebih dahulu. Kristen Saksisaksi Yehuwa memiliki dua kekeliruan dasar yang telah menyusun pemikiran teologi mereka. Kekeliruan tersebut adalah kekeliruan mereka mengenai Alkitab dan kekeliruan mereka mengenai pengajaran akan Allah.

Pertama, kekeliruan mengenai Alkitab. Kristen Saksi-saksi Yehuwa mempercayai bahwa Alkitab merupakan firman Allah yang tidak bersalah dan tidak mengandung kekeliruan. ${ }^{11}$ Sesuatu yang telah diilhamkan oleh Allah kepada para

Penerapan Konseling Expressive Writing Dalam Lingkup Pendidikan STUDI KEPUSTAKAAN PENERAPAN KONSELING EXPRESSIVE WRITING DALAM LINGKUP PENDIDIKAN Wilda Awalina Budi Purwoko Abstrak Studi Kepustakaan Penerapan Konseling Expressive Writing," Studi Kepustakaan Penerapan Konseling Expressive Writing dalam Lingkup Pendidikan STUDI 8, no. 2 (2018): 1-9.

11 “Alkitab Buku Dari Allah | Alkitab penulis Alkitab tidak mungkin di dalamnya terdapat kesalahan dan kekeliruan. Para penulis “didorong serta" oleh Tuhan. Oleh karena itu, Tuhan memakai setiap penulis, termasuk kepribadiannya untuk menyelesaikan karya ilahi yang otoritatif, dan Tuhan tidak pernah keliru dalam mengilhami. $^{12}$

\section{Akan tetapi, Kristen Saksi-saksi} Yehuwa tidak menerima Alkitab yang telah dipercayai oleh ajaran Kristen. Kristen Saksi-saksi Yehuwa menggunakan Alkitab yang diterjemahkan oleh mereka sendiri, yaitu Alkitab terjemahan Dunia Baru. Oleh karena itu, dalam menafsirkan Alkitab, Kristen Saksi-saksi Yehuwa berpatokan pada prinsip bahwa setiap ayat memiliki penilaian yang sama, tidak peduli oleh siapa diucapkan, kepada siapa, di mana, pada zaman mana dan dalam keadaan bagaimanapun. $^{13}$

Kedua, kekeliruan mengenai Allah. Agama Kristen Saksi-saksi Yehuwa mempercayai bahwa Allah yang benar adalah Yehuwa. ${ }^{14}$ Nama Yehuwa berasal dari bahasa Ibrani Yahwe, yang muncul

\footnotetext{
Ajarkan," Diakses Mei 24, 2021,

https://www.jw.org/id/perpustakaan /buku/alkitabajarkan/alkitab-buku-dari-allah/.

12 Jay Smith, 101 Penjelasan Mengenai

Tuduhan Kontradiksi Dalam Alkitab, n.d.

${ }^{13}$ Deky Nofa Aliyanto, "Tanggapan

Terhadap Kristologi Saksi Yehuwa Kristus Adalah Ciptaan Yang Pertama Berdasarkan Kolose 1:15," FIDEI: Jurnal Teologi Sistematika dan Praktika 2, no. 2 (2019): 346.

${ }^{14}$ Ismail, "Konsep Ketuhanan Menurut
} 
sebanyak 7000 kali. ${ }^{15}$ Sehingga Kristen Saksi-saksi Yehuwa hanya mempertahankan makna secara harfiah, tetapi tidak memaknai secara teologis dari nama Yahwe. ${ }^{16}$ Maka pandangan mereka, memandang Allah yang benar tidak layak disandang oleh oknum lain selain Yehuwa itu sendiri. Pandangan ini merupakan pandangan yang menganggap Allah hanya satu pribadi disebut monoteis.

\section{Kesalahan Konsep Kristologi Kristen}

Saksi-saksi Yehuwa Menurut Kolose 1:15

Kristologi Kristen Saksi-saksi Yehuwa memiliki beberapa pemahaman keliru dalam Kolose 1:15 karena dikarenakan oleh ada beberapa penafsiran yang salah terhadap teks. Sikap ini dilakukan oleh Saksi-saksi Yehuwa yang menyebabkan kesalahan konsep Kristologi Saksi-saksi Yehuwa.

Penafsiran kata "prōtotokos" (yang sulung) dalam Kolose 1:15. Menurut mereka, kata (prōtotokos) sebagai bukti bahwa Yesus adalah ciptaan pertama dan bukan sang pencipta. Menurut mereka, ada masa dimana pernah sekali waktu Allah (Yehuwa) itu berada dalam kesendirian. Kemudian Allah menggunakan kuasa-Nya

Kristen Saksi Yehuwa," Jurnal Sosiologi Agama 10, no. 2 (2017): 129.

15 “Alkitab Buku Dari Allah | Alkitab Ajarkan.”

${ }^{16}$ Bambang Noorsena, The History of Allah (Yogyakarta: ANDI, 2006). untuk menciptakan yang tak terselami guna membentuk suatu pribadi roh yang hidup dan cerdas yang bernama Yesus Kristus. Yesus sebagai Alfa dari ciptaan Allah dan karena itu Ia disebut sebagai satu-satunya putra Allah yang sulung atau yang pertama kali diciptakan dari antara semua ciptaan.

Ia adalah ciptaan Allah yang pertama (Kolose 1:15). Karena diciptakan maka Putra memiliki permulaan, sedangkan Allah Yewuha tidak punya awal atau akhir. ${ }^{17}$ Kepercayaan tersebut juga ditegaskan dalam buku yang telah mereka terbitkan dengan judul "Jehovah's Withnesses In The 20th Century". ${ }^{18}$ Persoalannya, meyakini Yesus Kristus sebagai ciptaan pertama yang diciptakan oleh Allah berarti menolak bahwa Yesus Kristus sepenuhnya Allah. Doktrin Kristologi Saksi-saksi Yehuwa tersebut jelas-jelas berbenturan dengan doktrin Kekristenan tradisional yang mengakui bahwa Yesus sepenuhnya adalah Allah dan sepenuhnya adalah manusia. Kesaksian Alkitab juga menunjukan bahwa Yesus Kristus adalah Alfa dan Omega, Yang Awal dan Yang Akhir.

Berdasarkan konsep kesalahan tersebuat, Saksi Yehuwa

\footnotetext{
${ }^{17}$ Apa Yang Sebenarnya Alkitab Ajarkan (Jakarta: Saksi-saksi Yehuwa Indonesia, 2013).

${ }^{18}$ Brooklyn, Jehovah's Withnesses In The 20th Century (New York: Wacthtower Bible and Tract Society, International Bible Students Association, 1978).
} 
mempresentasikan, Yesus Kristus merupakan pribadi yang diciptakan (Kolose 1:15). Kristus adalah pribadi kedua yang terbesar dalam alam semesta. Kemudian disebut sebagai orang pertama dan satu-satunya yang langsung diciptakan oleh Bapa-Nya. Sehingga Saksi Yehuwa, menyatakan Yesus Kristus bukanlah Allah, tetapi "suatu allah" atau "allah kecil", yaitu allah yang lebih rendah dari Allah (Yehuwa) yang maha kuasa. ${ }^{19}$ Sehingga pandangan ini, Yesus Kristus adalah ciptaan yang sulung (prōtotokos) yang kemudian diangkat Allah sebagai AnakNya dan rekan penciptaan (Ams. 8:22; Kol.1:15). ${ }^{20}$

\section{Kedudukan Kristus menurut Kolose 1:15}

Surat Kolose merupakan surat yang tergolong di dalam surat Penjara yang dituliskan oleh rasul Paulus kepada jemaat di Kolose. Surat ini berisi nasehat kepada jemaat di Kolose yang sedang menghadapi ajaran sesat. Penekanan di dalam surat Kolose adalah supaya jemaat di Kolose tetap berpegang teguh dengan iman Kristen meskipun mereka sedang diperhadapkan dengan pengajaran sesat yang tengah berkembang. Khususnya di dalam teks

${ }^{19}$ Dominggus, "Kedudukan Kristus Dalam Penciptaan Menurut Kolose 1:15-20 (Tanggapan Kristologi Saksi Yehuwa)."

${ }^{20}$ Pangeran Manurung, "Studi Eksegetis Yohanes 1:1-18 Sebagai Apologetik Terhadap Kristologi Saksi Yehuwa," Journal Kerusso 1, no. 2 (2016): 1-41.
Kolose 1:15, Paulus menekankan bahwa Yesus lebih tinggi dari segala yang ada di dalam dunia ini. ${ }^{21}$

Ada bagian berikutnya, Paulus menuliskan Kristus sebagai "yang sulung”, yang diterjemahkan dari kata Yunani

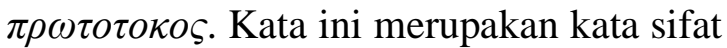

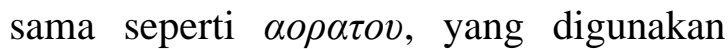
untuk menggambarkan sifat yang dimiliki Kristus di dalam penciptaan. H. Langkamer mengartikan kata ini sebagai hubungan Kristus dengan ciptaan. ${ }^{22}$

Jadi, Kristus sebagai yang sulung memiliki otoritas yang sama dengan Bapa adalah Tuhan Sang Pencipta.

\section{Menjawab Konsep Kristologi Kristen}

\section{Saksi-saksi Yehuwa}

Pada bagian sebelumnya telah diuraikan konsep Kristologi di dalam Kolose 1:15. Berdasarkan pandangan mereka, sangatlah perlu untuk melakukan penyelidikan guna menemukan kebenaran yang ada. Pada pandangan ini terletak pada penafsiran kata "yang sulung". Saksi Yehuwa menerjemahkan kata ini secara literal yakni dalam urutan waktu. Dengan menggunakan penafsiran ini maka penerjemahan yang didapatkan adalah

\footnotetext{
${ }^{21}$ Dominggus, "Kedudukan Kristus

Dalam Penciptaan Menurut Kolose 1:15-20

(Tanggapan Kristologi Saksi Yehuwa)."

${ }^{22}$ Gerhard Schneider Horst Balz, "Exegetical Dictionary of the New Testament," Wm. B. Eerdmans Publishing 3 (1993): 347.
} 
Kristus adalah ciptaan. Jadi, pandangan ini muncul karena adanya kesalahan penafsiran.

Tindakan yang dilakukan oleh Saksi Yehuwa adalah tindakan yang keliru. Mereka hanya menggunakan pendekatan urutan waktu saja tanpa memperhatikan kemungkinan penafsiran yang lainnya. Jika ditinjau lebih dalam, kata sulung memiliki kemungkinan penafsiran dari segi otoritas dan hubungan. Karena itu, untuk mendapatkan penafsiran yang benar haruslah memeriksa setiap kemungkinan yang ada.

Sehingga penulis menjawab konsep Kristologi Kristen Saksi-saksi Yehuwa berdasarkan eksegesis Kolose 1:15 dengan pemberian pemahaman yang benar, bahwa Kristus adalah yang utama dari segala hal. Pandangan ini muncul karena Paulus menafsirkan frase "yang sulung" dalam arti otoritas atau hubungan. ${ }^{23}$ Dengan demikian, Kristus adalah Allah yang merupakan pelaku dari penciptaan. Pandangan Paulus dan Saksi Yehuwa mengenai kedudukan Kristus sangatlah bertolak belakang. Saksi-saksi Yehuwa memandang Kristus hanya sebatas ciptaan sedangkan Paulus memandang Kristus sebagai pencipta. Namun dari kedua pandangan ini, pandangan Kristus sebagai pencipta adalah pandangan yang benar.

${ }^{23}$ Dominggus, "Kedudukan Kristus

\section{KESIMPULAN}

Kesalahpahaman

Kristologi merupakan kekeliruan dalam menafsirkan sepenggal ayat-ayat dalam Alkitab dan sumber Alkitab yang tidak bersumber pada Alkitab LAI. Seperti hal, kelompok Kristen Saksi-saksi Yehuwa dalam pandangan Kristologi mereka dalam Kolose 1:15, bahwa Kristus Yesus bukan Allah Sang Pencipta karena Ia adalah "yang sulung" dari ciptaan Allah (Yehuwa). Ia "suatu allah" tetapi bukan Allah sejati. Maka golongan ini perlu mendapat pemahaman tentang Kolose 1:15 "yang sulung" dalam arti otoritas atau hubungan. Dengan demikian, Kristus adalah Allah yang merupakan pelaku dari penciptaan. Pandangan ini, pandangan Kristus sebagai pencipta adalah pandangan yang benar sesuai dengan kajian biblical.

\section{DAFTAR PUSTAKA}

Aliyanto, Deky Nofa. "Tanggapan Terhadap Kristologi Saksi Yehuwa Kristus Adalah Ciptaan Yang Pertama Berdasarkan Kolose 1:15.” FIDEI: Jurnal Teologi Sistematika dan Praktika 2, no. 2 (2019): 346.

Awalina, Wilda. "Studi Kepustakaan Penerapan Konseling Expressive Writing Dalam Lingkup Pendidikan STUDI KEPUSTAKAAN

Dalam Penciptaan Menurut Kolose 1:15-20 (Tanggapan Kristologi Saksi Yehuwa).” 
PENERAPAN

KONSELING

EXPRESSIVE WRITING DALAM

LINGKUP PENDIDIKAN Wilda

Awalina Budi Purwoko Abstrak Studi

Kepustakaan Penerapan Konseling

Expressive Writing.” Studi

Kepustakaan Penerapan Konseling

Expressive Writing dalam Lingkup

Pendidikan STUDI 8, no. 2 (2018): 19.

Brooklyn. Jehovah's Withnesses In The 20th Century. New York: Wacthtower Bible and Tract Society, International Bible Students Association, 1978.

Charles F. Pfeiffer, Everett F. Harrison.

The WYCLIFFE Bible Commentary

(Volume 3). Edited by Emma

Maspaitella. V. Malang: Gandum

Mas, 2014.

Dominggus, Dicky. "Kedudukan Kristus

Dalam Penciptaan Menurut Kolose

1:15-20 (Tanggapan Kristologi Saksi

Yehuwa)." Religi: Jurnal Studi

Agama-agama 16, no. 1 (2020): 4263.

Horst Balz, Gerhard Schneider.

"Exegetical Dictionary of the New

Testament." Wm. B. Eerdmans

Publishing 3 (1993): 347.

Ismail. "Konsep Ketuhanan Menurut

Kristen Saksi Yehuwa." Jurnal

Sosiologi Agama 10, no. 2 (2017):

129.
Ismail, Roni. "Konsep Ketuhanan Menurut Kristen Saksi Yehuwa.” Jurnal Sosiologi Agama 10, no. 2 (2017): 83. John Calvinnis. INSTITUTIO : Pengajaran Agama Kristen. Edited by Staf Redaksi BPK Gunung Mulia. XI. Jakarta: Gunung Mulia, 2015. http://www.bpkgunungmulia.com.

Kin Maryati, Juju Suryawati. Sosiologi. Jakarta: Erlangga, 2007.

Manurung, Pangeran. "Studi Eksegetis Yohanes 1:1-18 Sebagai Apologetik Terhadap Kristologi Saksi Yehuwa.” Journal Kerusso 1, no. 2 (2016): 141.

Noorsena, Bambang. The History of Allah. Yogyakarta: ANDI, 2006.

Smith, Jay. 101 Penjelasan Mengenai Tuduhan Kontradiksi Dalam Alkitab, n.d.

"Alkitab Buku Dari Allah | Alkitab Ajarkan." Diakses Mei 24, 2021. https://www.jw.org/id/perpustakaan /buku/alkitab-ajarkan/alkitab-bukudari-allah/.

Apa Yang Sebenarnya Alkitab Ajarkan. Jakarta: Saksi-saksi Yehuwa Indonesia, 2013.

“Apakah Yesus Allah Yang Mahakuasa? | Pertanyaan Alkitab.” Diakses Mei 24, 2021. 